\title{
Rainfall over the Arid Area in the Northwestern China
}

\author{
- An Analysis during HEIFE -
}

\author{
By Toshihisa Itano ${ }^{1}$ \\ Disaster Prevention Research Institute, Kyoto University, Gokasyo, Uji, Kyoto 611, Japan
}

(Manuscript received 27 April 1995, in revised form 2 June 1997)

\begin{abstract}
Synoptic characteristics of precipitation over the HEIFE area in Northwestern China are investigated. The results show that rainfall in the HEIFE area is caused by disturbance on the polar frontal troughs, and the rain area covers the whole HEIFE area of $200 \times 100 \mathrm{~km}$. However, the amount of rainfall depends on the altitude, e.g. $600 \mathrm{~mm} /$ year in the Qilian Mountains at $3000 \mathrm{mASL}$ and only $100 \mathrm{~mm} /$ year or less at the bottom flat of the valley called "Hexi Corridor" at around $1300 \mathrm{mASL}$.

During summer, the water vapor content is rather large and stratification of the air over the desert shows potential instability. However, because of the high lifting condensation level (LCL) and the free convection level (LFC) over the desert, isolated cumulus convections do not develop, in spite of the large buoyancy induced by high ground temperatures. As a result, rainfall over the HEIFE area occurs when the disturbances on the polar frontal trough move into the area. The total amount of rainfall observed in the lower land of the HEIFE area, however, seems to be significantly reduced due to the evaporation of raindrops within the deep and dry boundary layer. Meanwhile, in winter, the water vapor content is quite small and stability is nearly neutral, which accounts for the low precipitation in this area.
\end{abstract}

\section{Introduction}

In Northwestern China, there are vast arid and semi-arid areas, the dryness of which is traditionally explained by the geological isolation from a source of water. Another explanation emphasizes that salt within the soil excludes plants, which causes the soil surface to dry up. Such salt is considered to be maritime in origin, transported from sea by the general circulation and accumulated during the climatological ages because there is no drainage into the sea from this area (e.g. Rossby, 1957). Several authors (e.g. Manabe, 1969; Walker and Rowntree, 1977) have suggested that the reduced soil moisture decreases the evaporation and thus the rainfall. On the other hand, Manabe and Broccoli (1990) and Broccoli and Manabe (1992) emphasized the effects of the Tibetan Plateau on the formation of the arid area in the midlatitudes, as the Plateau produces a stationary trough downstream within the midlatitude westerly jet. Meanwhile, it is shown that the desert area in Northwestern China is under the descending branch of the meridional circulation driven by the elevated heat source of the Tibetan Plateau

1 Present affiliation: Department of Geoscience, National Defense Academy, Yokosuka 239, Japan

(c) 1997, Meteorological Society of Japan during summer (e.g. Ye, 1981, Yanai et al.,1991). Such descending air motions may suppress the convective activities over the desert in spite of a high ground temperature at the surface.

The amount and trend of rainfall is a controlling factor in desertification. Climatologically, the annual precipitation in the arid and semi-arid areas of Northwestern China is less than $100 \mathrm{~mm}$ (Domrös and Peng 1988). Most of the rainfall concentrates in summer(Yatagai and Yasunari, 1995), which is closely related to the Asian summer Monsoon (Lau et al., 1988). Interannually, rainfall has some relationship with ENSO (Wang and Li, 1990) and/or the interannual activity of the Monsoon (Yatagai and Yasunari, 1995). Meanwhile, daily rainfall is strongly affected by synoptic weather conditions under the midlatitude westerly jet even in the arid and semi-arid areas of Northwestern China.

The purpose of this study is to clarify the characteristics and conditions of precipitation over the arid areas in the Northwestern China as a part of HEIFE (Heihe River Basin Field Experiment, 19891993) which is one of the Hydrology Atmospheric Pilot Experiments (HAPEX) of WCRP operated in the Gansu Province of China around $39^{\circ} \mathrm{N}, 100^{\circ} \mathrm{W}$ (Fig. 1). The study is based on the analysis of daily rainfall records and their relationship to synoptic 


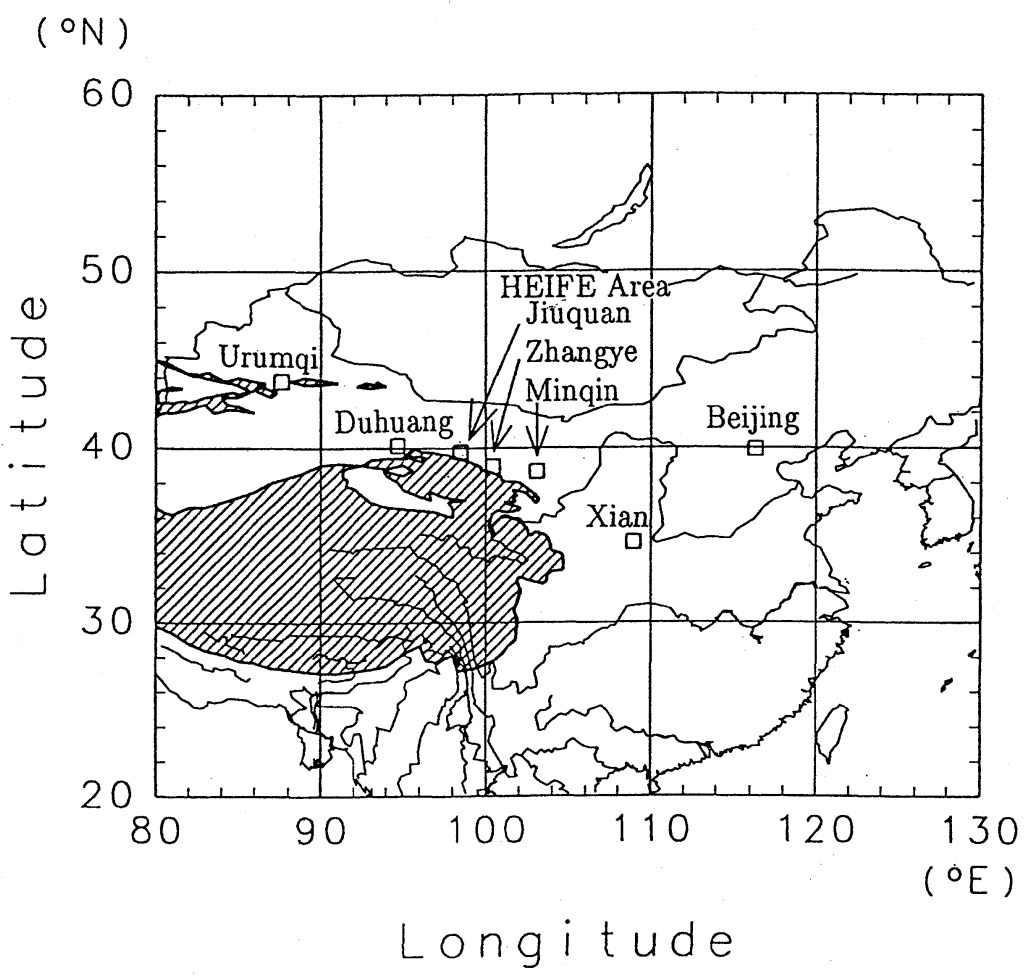

Fig. 1. Geographical location of the HEIFE area. The area of elevation higher than 3000 mASL is shaded.

weather conditions is focused on.

\section{Geography and observed data}

The experimental area is in the skirt of the Qilian Mountains on the northeastern end of the QinghaiTibetan Plateau, including the middle reaches of the Heihe River which flows from the glaciers on the Qilian Mountains and terminates in the Mongolian Desert to the north. The Qilian Mountains ranging to about $5000 \mathrm{mASL}$ is on the southwestern side of this area, and the Longshou Mountains ranging to about $2000 \mathrm{mASL}$ to the east. A narrow valley called the "Hexi Corridor", two thirds of which is occupied by deserts, runs from NW to SE between the Qilian Mountains and the Longshou Mountains. The HEIFE observation field (see Fig. 2) is a part of the Hexi Corridor that includes deserts, oases, forests and some irrigated farm land (Wang, 1993).

The main data used for this analysis are as follows:

1. the aerological data with significant point data at Jiuquan $\left(39^{\circ} 46^{\prime} \mathrm{N}, 98^{\circ} 29^{\prime} \mathrm{E}\right)$, Zhangye $\left(38^{\circ} 56^{\prime} \mathrm{N}, \quad 100^{\circ} 26^{\prime} \mathrm{E}\right)$ and Minqin $\left(38^{\circ} 38^{\prime} \mathrm{N}\right.$, $103^{\circ} 05^{\prime} \mathrm{E}$ ) observed at $0730 \mathrm{BST}$ and $1930 \mathrm{BST}$ for the period from August, 1990 to December, 1991

2. the twice-a-day rainfall data at Gaotai $\left(39^{\circ} 22^{\prime} \mathrm{N}, 9^{\circ} 50^{\prime} \mathrm{E}\right)$, Linze $\left(39^{\circ} 09^{\prime} \mathrm{N}, 100^{\circ} 10^{\prime} \mathrm{E}\right)$ and Zhangye from August, 1990 to December, 1991 which is a data set including the daytime rainfall (from $08 \mathrm{BST}$ to $20 \mathrm{BST}$ ) and the night- time rainfall (from $20 \mathrm{BST}$ to $08 \mathrm{BST}$ of the following day)

3. the daily rainfall data set of local hydrological network of Hydrological Servic of Gansu Province observed from 08 BST to 08 BST of the following day for the period 1988-1991.

The locations of the stations are shown in Table 1.

In addition to these three data sets, the following data were also used to complete the analysis:

4. the fixed-point aerological data at Duhuang $\left(40^{\circ} 09^{\prime} \mathrm{N}, \quad 94^{\circ} 41^{\prime} \mathrm{E}\right)$ and Xian $\left(34^{\circ} 18^{\prime} \mathrm{N}\right.$, $\left.108^{\circ} 56^{\prime} \mathrm{E}\right)$ in August, 1991

5. the GMS-4 S-VISSR infrared data received at the Disaster Prevention Research Institute, Kyoto University, from which $T_{B B}$ is calculated by using the conversion table, and so on.

\section{Rainfall characteristics over the HEIFE area}

Annual precipitation in and around the HEIFE area for 1988-1991 is summarized in Table 1. In this table, stations are classified into the following three groups: the desert area including oases extending at the bottom of the Hexi Corridor, the Qilian Mountain range just southwest of the Hexi Corridor, and the Longshou Mountain range just northeast of the Hexi Corridor. Their elevations above sea level are $1300-1500 \mathrm{~m}, 1700-3200 \mathrm{~m}$ and $1900-2000 \mathrm{~m}$, 


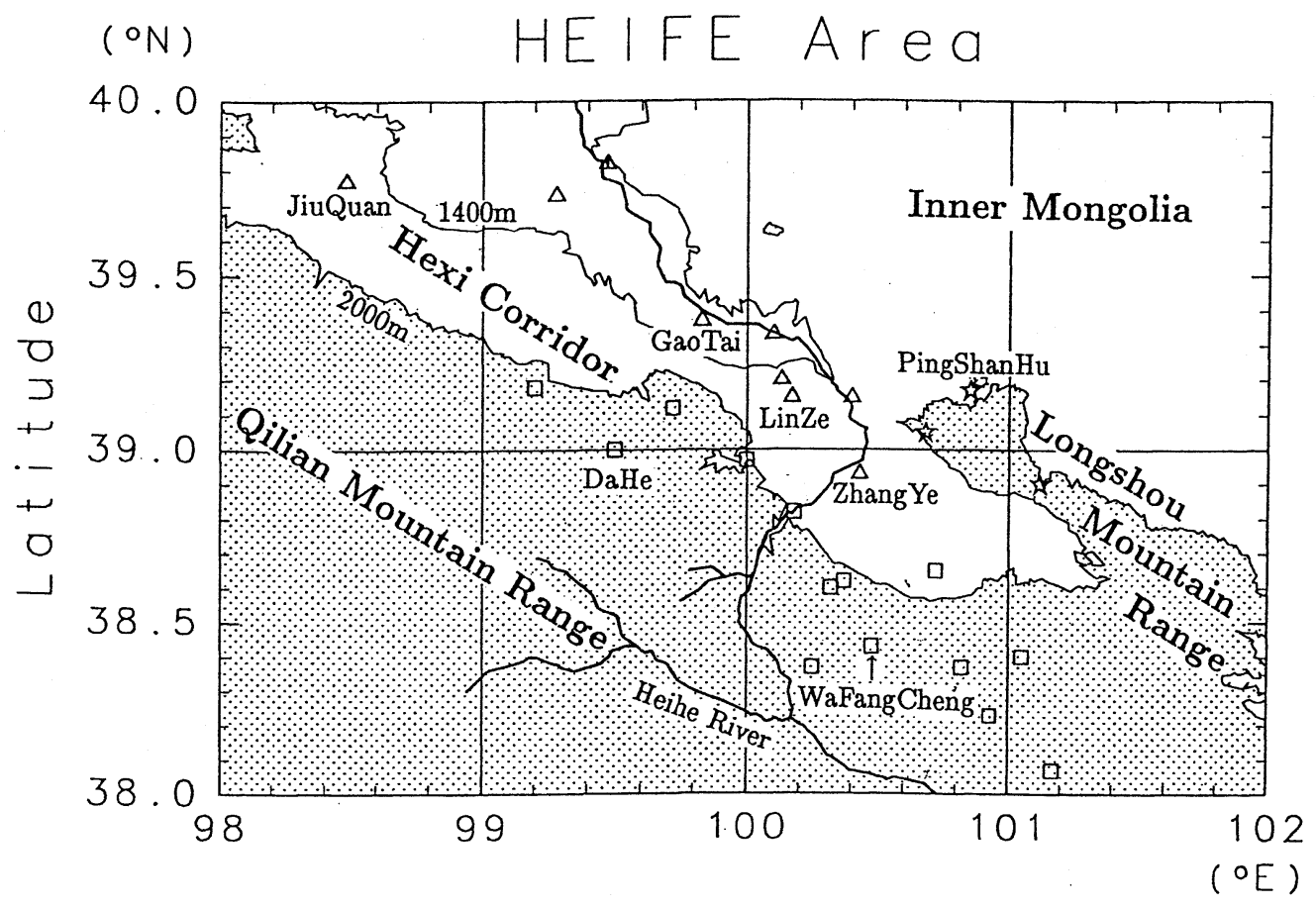

Longitude

Fig. 2. Local map of the HEIFE area. The mountainous area higher than $2000 \mathrm{mASL}$ is shaded. Stations are classified into three categories as follows (see Table.1): desert area including oases at the bottom of the Hexi Corridor (triangle), the Qilian Mountain Range (square) and the Longshou Mountain Range (star).

Table 1. Annual precipitation and locations of three basic stations of Chinese Weather Service (GaoTai, LinZe and ZhangYe) and the other local hydrological networks.

\begin{tabular}{|c|c|c|c|c|c|c|c|}
\hline & \multicolumn{3}{|c|}{ Rainfall(mm/year) } & \multicolumn{3}{c|}{ Location } \\
\hline Station/Year & 1988 & 1989 & 1990 & 1991 & Longitude & Latitude & Elevation \\
\hline GaoTai & $/$ & $/$ & $/$ & 95.2 & $99^{\circ} 50^{\prime} \mathrm{E}$ & $39^{\circ} 22^{\prime} \mathrm{N}$ & $1332.2 \mathrm{~m}$ \\
LinZe & $/$ & $/$ & $/$ & 91.3 & $100^{\circ} 10^{\prime} \mathrm{E}$ & $39^{\circ} 09^{\prime} \mathrm{N}$ & $1453.7 \mathrm{~m}$ \\
ZhangYe & $/$ & $/$ & $/$ & ${ }^{*} 84.7$ & $100^{\circ} 26^{\prime} \mathrm{E}$ & $38^{\circ} 56^{\prime} \mathrm{N}$ & $1482.7 \mathrm{~m}$ \\
GaoYao & 146.9 & 92.1 & 133.7 & 75.2 & $100^{\circ} 24^{\prime} \mathrm{E}$ & $39^{\circ} 09^{\prime} \mathrm{N}$ & $1415.0 \mathrm{~m}$ \\
PingChuan & 129.1 & 119.6 & $/$ & 80.3 & $100^{\circ} 06^{\prime} \mathrm{E}$ & $39^{\circ} 20^{\prime} \mathrm{N}$ & $1382.0 \mathrm{~m}$ \\
ShuangQuanHu & 99.6 & 94.8 & $/$ & $/$ & $100^{\circ} 08^{\prime} \mathrm{E}$ & $39^{\circ} 12^{\prime} \mathrm{N}$ & $1430.0 \mathrm{~m}$ \\
YanChi & 82.9 & 44.7 & $/$ & 73.9 & $99^{\circ} 17^{\prime} \mathrm{E}$ & $39^{\circ} 44^{\prime} \mathrm{N}$ & $1330.0 \mathrm{~m}$ \\
ZhengYiXia & 84.9 & 52.7 & 103.2 & 72.2 & $99^{\circ} 28^{\prime} \mathrm{E}$ & $39^{\circ} 49^{\prime} \mathrm{N}$ & $1310.0 \mathrm{~m}$ \\
\hline \multicolumn{8}{|c|}{ Desert in the Bottom of the Hexi Corridor } \\
\hline
\end{tabular}

\begin{tabular}{|c|c|c|c|c|r|c|c|}
\hline BaiShiYa & 653.7 & 494.9 & 434.9 & $/$ & $101^{\circ} 10^{\prime} \mathrm{E}$ & $38^{\circ} 04^{\prime} \mathrm{N}$ & $3200.0 \mathrm{~m}$ \\
BianDuKou & $/$ & $/$ & 444.3 & 383.1 & $100^{\circ} 56^{\prime} \mathrm{E}$ & $38^{\circ} 14^{\prime} \mathrm{N}$ & $2810.0 \mathrm{~m}$ \\
BingGouTai & 485.3 & 652.3 & $/$ & 329.4 & $100^{\circ} 50^{\prime} \mathrm{E}$ & $38^{\circ} 17^{\prime} \mathrm{N}$ & $2660.0 \mathrm{~m}$ \\
DaHe & 278.2 & 322.6 & 298.7 & 214.4 & $99^{\circ} 30^{\prime} \mathrm{E}$ & $39^{\circ} 00^{\prime} \mathrm{N}$ & $2660.0 \mathrm{~m}$ \\
DaYeKou & $/$ & 390.3 & $/$ & 261.7 & $100^{\circ} 19^{\prime} \mathrm{E}$ & $38^{\circ} 36^{\prime} \mathrm{N}$ & $2400.0 \mathrm{~m}$ \\
HongShaHe & 288.4 & 231.8 & $/$ & 207.4 & $99^{\circ} 12^{\prime} \mathrm{E}$ & $39^{\circ} 11^{\prime} \mathrm{N}$ & $2290.0 \mathrm{~m}$ \\
HuaZhai & 206.3 & 346.0 & 296.2 & $/$ & $100^{\circ} 22^{\prime} \mathrm{E}$ & $38^{\circ} 37^{\prime} \mathrm{N}$ & $2160.0 \mathrm{~m}$ \\
HuoCheng & 396.9 & 399.7 & $/$ & 242.6 & $101^{\circ} 03^{\prime} \mathrm{E}$ & $38^{\circ} 24^{\prime} \mathrm{N}$ & $2400.0 \mathrm{~m}$ \\
LiYuanBao & 198.2 & 174.9 & 152.3 & $/$ & $100^{\circ} 00^{\prime} \mathrm{E}$ & $38^{\circ} 58^{\prime} \mathrm{N}$ & $1760.0 \mathrm{~m}$ \\
LiuBa & 217.8 & 184.8 & $/$ & 152.3 & $100^{\circ} 43^{\prime} \mathrm{E}$ & $38^{\circ} 39^{\prime} \mathrm{N}$ & $1820.0 \mathrm{~m}$ \\
ShuanShuSi & 399.8 & 467.2 & 350.1 & 271.5 & $100^{\circ} 49^{\prime} \mathrm{E}$ & $38^{\circ} 22^{\prime} \mathrm{N}$ & $2410.0 \mathrm{~m}$ \\
WaFangCheng & 462.8 & 504.8 & 381.6 & 319.5 & $100^{\circ} 29^{\prime} \mathrm{E}$ & $38^{\circ} 26^{\prime} \mathrm{N}$ & $2440.0 \mathrm{~m}$ \\
XiShui & 380.2 & $/$ & $/$ & $/$ & $100^{\circ} 15^{\prime} \mathrm{E}$ & $38^{\circ} 22^{\prime} \mathrm{N}$ & $2760.0 \mathrm{~m}$ \\
YaoGao & 187.0 & 344.2 & 194.9 & $/$ & $99^{\circ} 43^{\prime} \mathrm{E}$ & $39^{\circ} 07^{\prime} \mathrm{N}$ & $2380.0 \mathrm{~m}$ \\
YingLuoXia & 212.3 & 147.4 & 155.8 & 120.4 & $100^{\circ} 11^{\prime} \mathrm{E}$ & $38^{\circ} 49^{\prime} \mathrm{N}$ & $1700.0 \mathrm{~m}$ \\
\hline
\end{tabular}

\begin{tabular}{|c|c|c|c|r|r|r|r|}
\hline DongShanSi & 166.7 & 130.7 & 193.7 & $/$ & $100^{\circ} 41^{\prime} \mathrm{E}$ & $39^{\circ} 03^{\prime} \mathrm{N}$ & $1900.0 \mathrm{~m}$ \\
HongSiHu & 185.9 & 71.4 & $/$ & 99.0 & $101^{\circ} 07^{\prime} \mathrm{E}$ & $38^{\circ} 54^{\prime} \mathrm{N}$ & $2040.0 \mathrm{~m}$ \\
PingShanHu & 236.8 & 109.5 & 207.1 & 128.3 & $100^{\circ} 51^{\prime} \mathrm{E}$ & $39^{\circ} 10^{\prime} \mathrm{N}$ & $1880.0 \mathrm{~m}$ \\
\hline
\end{tabular}

*; obtained in the period between October 1990 and September 1991

/; data not taken 
( $m$ )

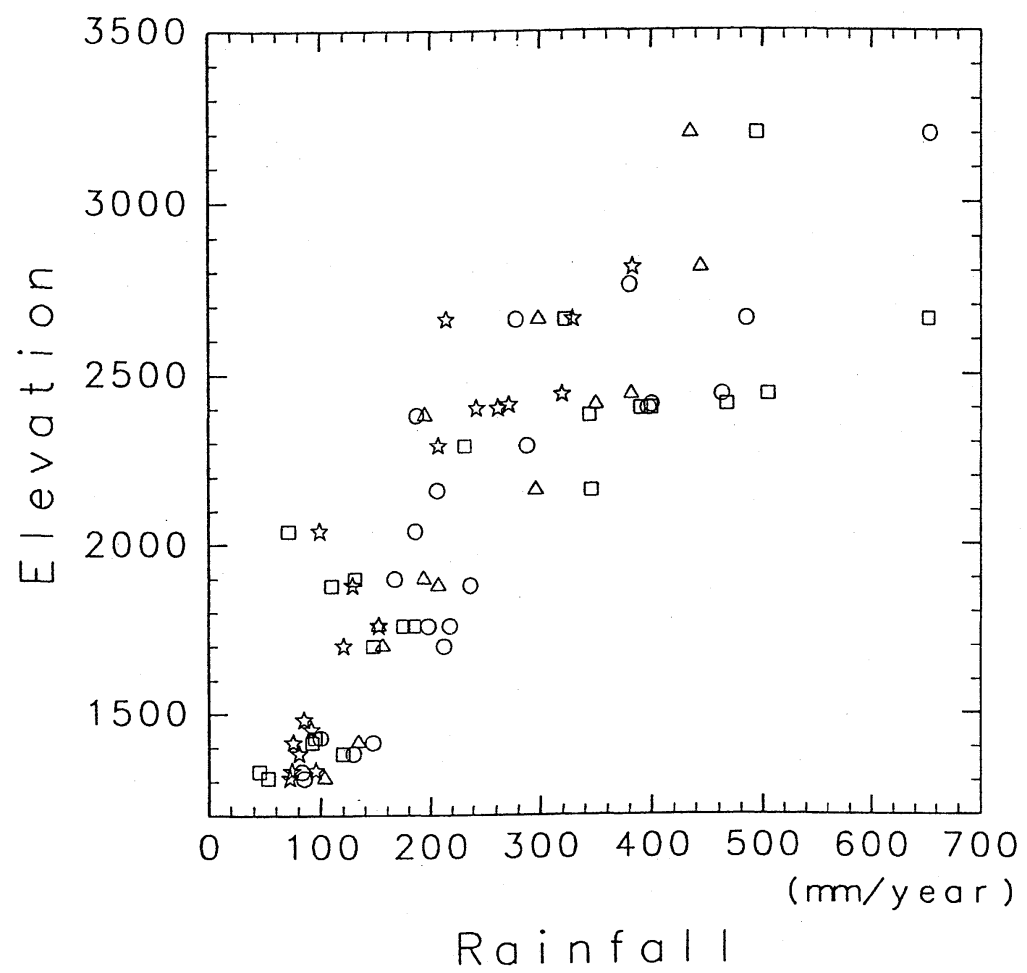

Fig. 3. Relation between the annual precipitation and the elevation of stations for 1988-91. Circles, squares, triangles and stars indicate the observations made in 1988, 1989, 1990 and 1991, respectively.

respectively. Generally, the higher the elevations of stations, the larger the precipitation within the area. In fact, the annual precipitation has nearly a linear relation with the elevation of the station, as shown in Fig. 3, and is less dependent on the horizontal locations and/or the land cover, such as a desert or an oasis. More than $600 \mathrm{~mm} /$ year of rainfall was observed at the Qilian Mountain range, while only $100 \mathrm{~mm} /$ year or less at the bottom part of Hexi Corridor.

Figure 4 shows a set of time series of daily rainfall at the stations in the HEIFE area during 1991, which is arranged according to their elevations. The rainfall at each station is relatively large in summer and small or zero in winter, and the rainfall occurs simultaneously over an area of $200 \times 100 \mathrm{~km}$. As will be discussed in later sections, this is because rainfall in this area is caused by large-scale organized systems, not by sporadic cumulus convections on small scales. Sometimes, the rainfall was observed only at higher elevated stations, whereas little or no rain was seen at the lower ones, which results in the difference of the annual precipitation as shown in Fig. 3. Although this feature may be explained as orographic rainfall to some extent, it is more possibly due to the evaporation of the rain drops formed in the upper atmosphere before reaching the ground surface in lower-elevated desert areas. This point will be discussed later in more detail.

\section{Vertical structure of the atmosphere over the desert}

\subsection{Water vapor content}

Before proceeding to the detailed analysis of the rainfall data, the atmospheric conditions over the HEIFE area are examined. The precipitable water, which is defined as the amount of water vapor contained in a vertical air column of unit cross-sectional area, is calculated from;

$$
\text { Precipitable Water }=-\frac{1}{g} \int_{P=P_{\text {surface }}}^{P=0} q d P,
$$

where $g$ the acceleration of gravity, $q$ the mixing ratio and $\mathrm{P}$ the air pressure. Generally, the small amount of rainfall over the arid areas of northwestern China is attributed to the smallness of this value.

Figure 5 shows a time series of the precipitable water at ZhangYe. Although the day-to-day variation is quite large, the seasonal cycle is quite clear, showing the maximum value reaching $35 \mathrm{~kg} \mathrm{~m}^{-2}$ in August while the minimum value is less than $2 \mathrm{~kg} \mathrm{~m}^{-2}$ in winter, which results in little rain in winter. The seasonal cycle of the precipitable water shows a sharp increase late in May and a distinct decrease in mid-September. During the warm seasons between the two sharp changes, the polar front is normally to the north of this area and the jet stream flows north of the Tibetan Plateau. Therefore, the 


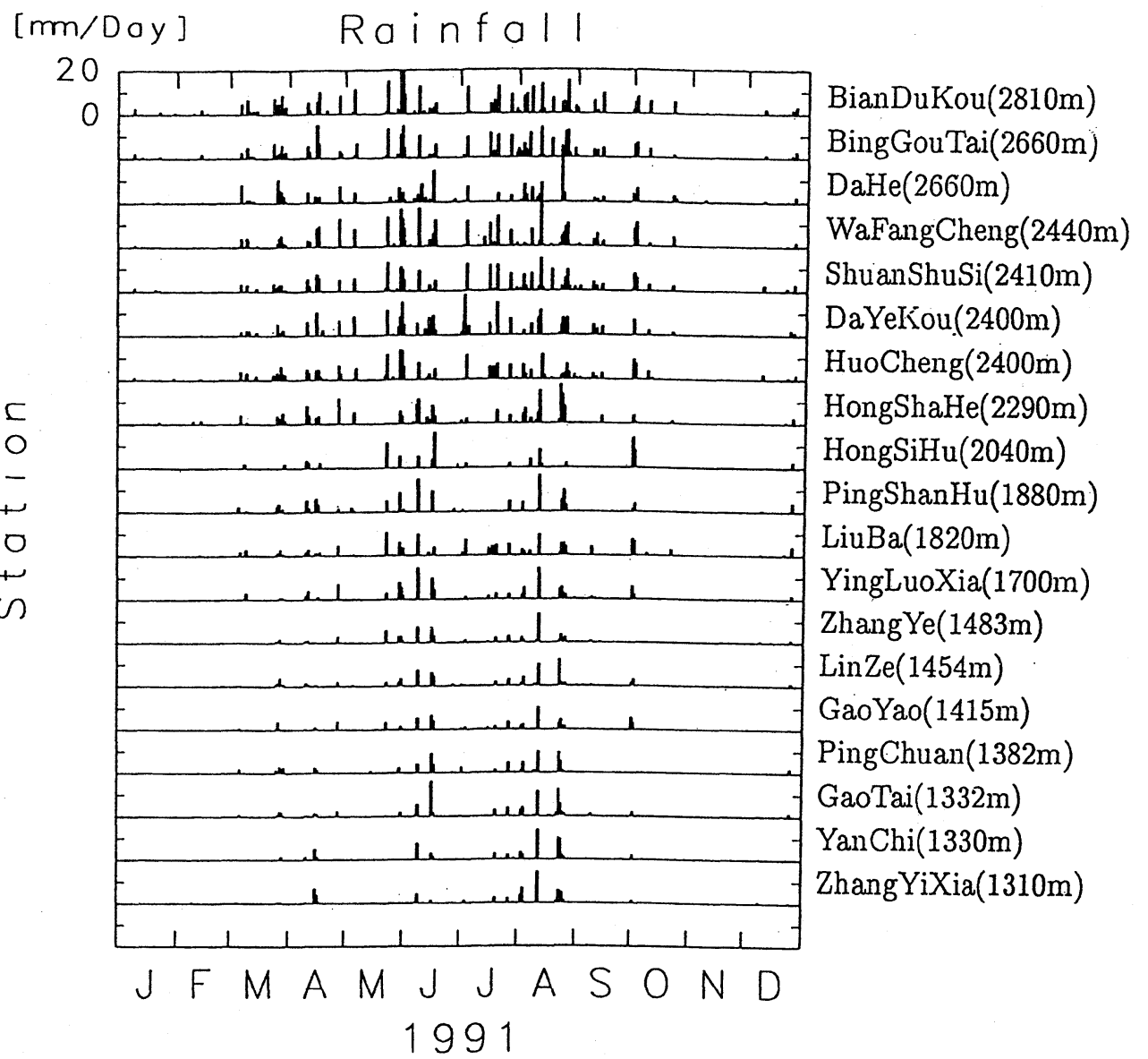

Fig. 4. Time series of daily rainfall amount at the stations within the HEIFE area in 1991 arranged according to their elevations (shown in parentheses).

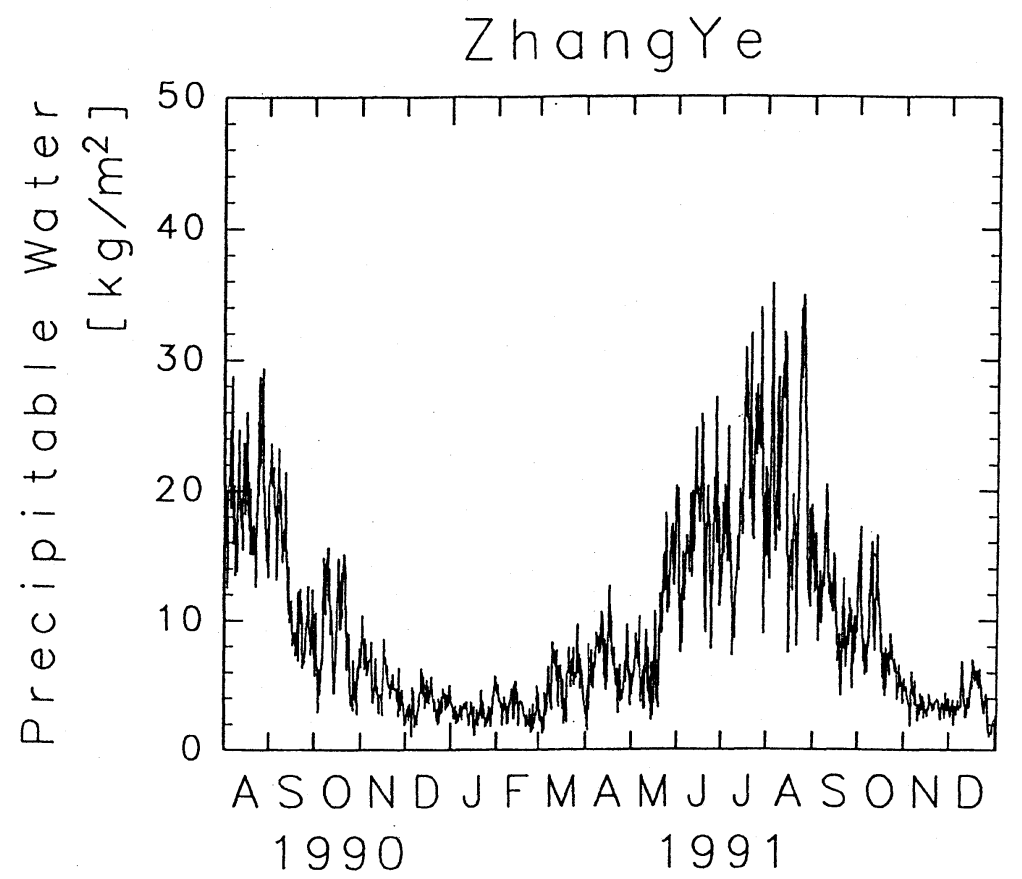

Fig. 5. Time series of precipitable water at ZhangYe from August 1, 1990 to the end of 1991. 


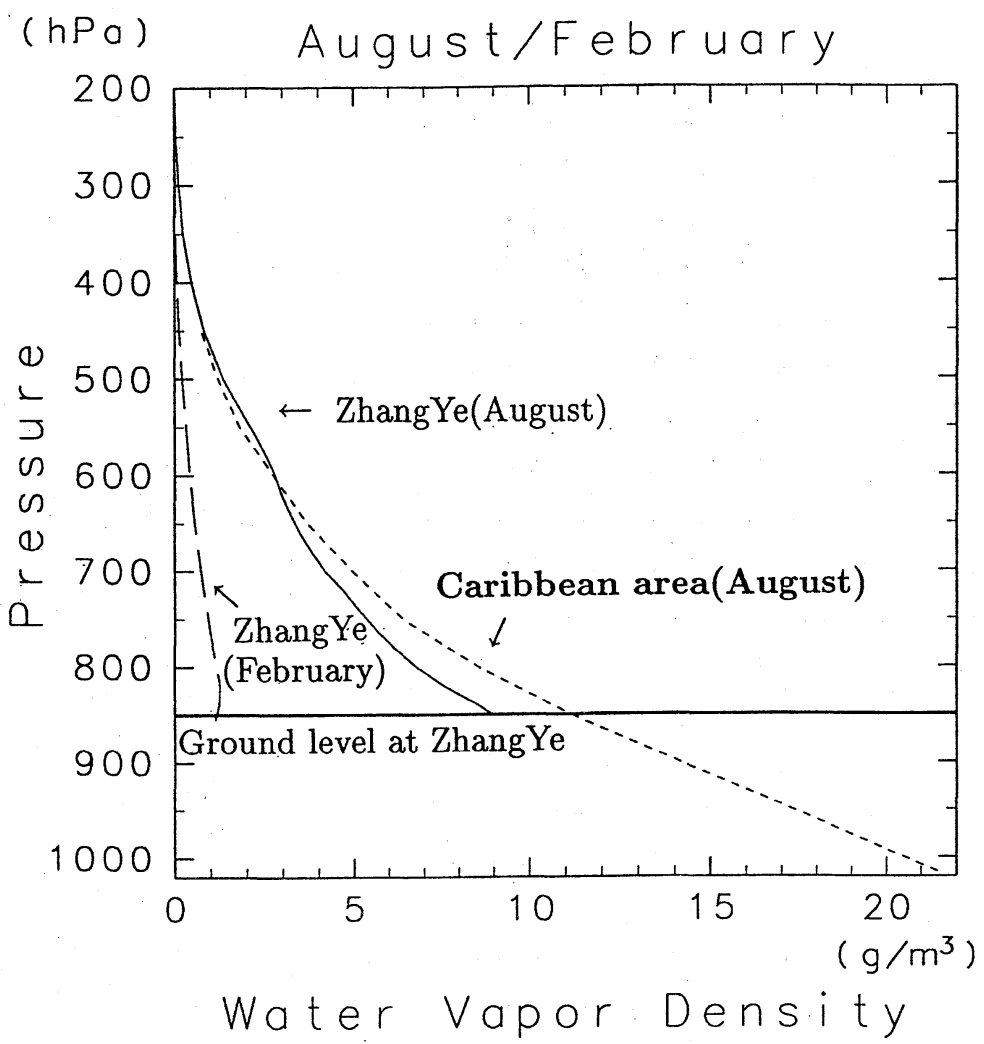

Fig. 6. Vertical profiles of monthly mean water vapor density at ZhangYe for August 1991 (solid line) and February 1991 (long-dashed line). For comparison, the profile in the Caribbean area in August calculated from the data from Jordan (1958) is also drawn with a short-dashed line.

water vapor is transported mainly from the west (Kitoh et al., 1993), however, the transport from southeast is seen sometimes in the lower troposphere when precipitation occurs (Mitsuta and Itano, 1993, Yatagai and Yasunari, 1993). The time series of precipitable water shows fluctuations of shorter periods (5-15 days), which implies the effects of the synoptic disturbances passing through this region. This feature can be found also in the data taken at two other weather stations of JiuQuan and MinQin in the HEIFE area.

Vertical profiles of monthly mean water vapor density in August and February at ZhangYe are shown in Fig. 6. For a comparison, the profile in the Caribbean area calculated from the data from Jordan (1958), the average of ten-year records at three stations in that area[Miami $\left(25^{\circ} 49^{\prime} \mathrm{N}\right.$, $\left.80^{\circ} 17^{\prime} \mathrm{W}\right)$, San Juan $\left(18^{\circ} 26^{\prime} \mathrm{N}, 6^{\circ} 00^{\prime} \mathrm{W}\right)$ and Swan Island $\left.\left(17^{\circ} 24^{\prime} \mathrm{N}, 83^{\circ} 56^{\prime} \mathrm{W}\right)\right]$ is also plotted as a representative feature in humid areas. In summer, the atmosphere over ZhangYe has a water vapour content of more than $75 \%$ of that measured in the Caribbean area at similar altitudes. In this respect, water vapor content of the air at high altitudes is large even in the arid area of northwestern China.

The vertical profile of relative humidity in August shown in Fig. 7 indicates that in spite of a small difference in water vapor content (as shown in Fig.
6), the relative humidity in the lower atmosphere at ZhangYe is quite low compared with that in the Caribbean area due to the high air temperature in the desert boundary layer. In February, the relative humidity is quite low due to the small moisture content there.

The time sequence of monthly mean precipitable water at ZhangYe is shown in Fig. 8 together with monthly rainfall amounts at ZhangYe and WaFangCheng in the Qilian Mountains. During the summer from June to August, the monthly mean values of precipitable water were relatively large and approaching around $20 \mathrm{~kg} \mathrm{~m}^{-2}$, which was about twice the levels for the months before and after these three summer months. Compared with the precipitable water $47.5 \mathrm{~kg} \mathrm{~m}^{-2}$ in the Caribbean area in August calculated from the data from Jordan (1958), the precipitable water in the HEIFE area during the summer months is about one-half. However, the rainfall observed at ZhangYe is about $20 \mathrm{~mm}$ in August and much smaller than that in the Caribbean area. The monthly rainfall in $\mathrm{Au}^{-}$ gust was $178.4 \mathrm{~mm}$ at Miami, and its ratio to the monthly mean precipitable water was about 4 , while it was only 1.2 at ZhangYe. If this ratio were the same as that in the humid area, the monthly rainfall at ZhangYe should be about $80 \mathrm{~mm}$ in August, which was comparable to the actual rainfall $65.1 \mathrm{~mm}$ 


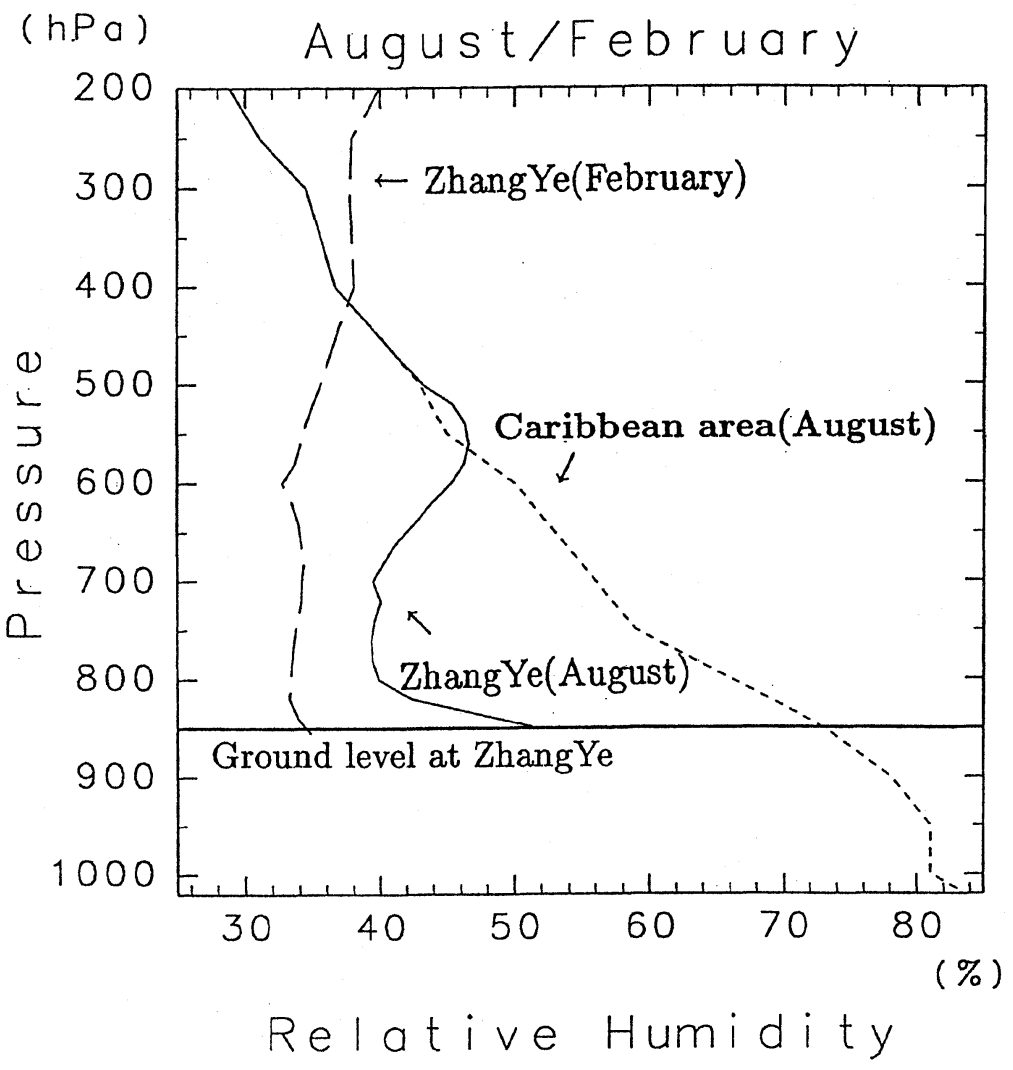

Fig. 7. Same as Fig. 6, except for the relative humidity.

$\left[\mathrm{mm}\left(=\mathrm{kg} / \mathrm{m}^{2}\right)\right]$

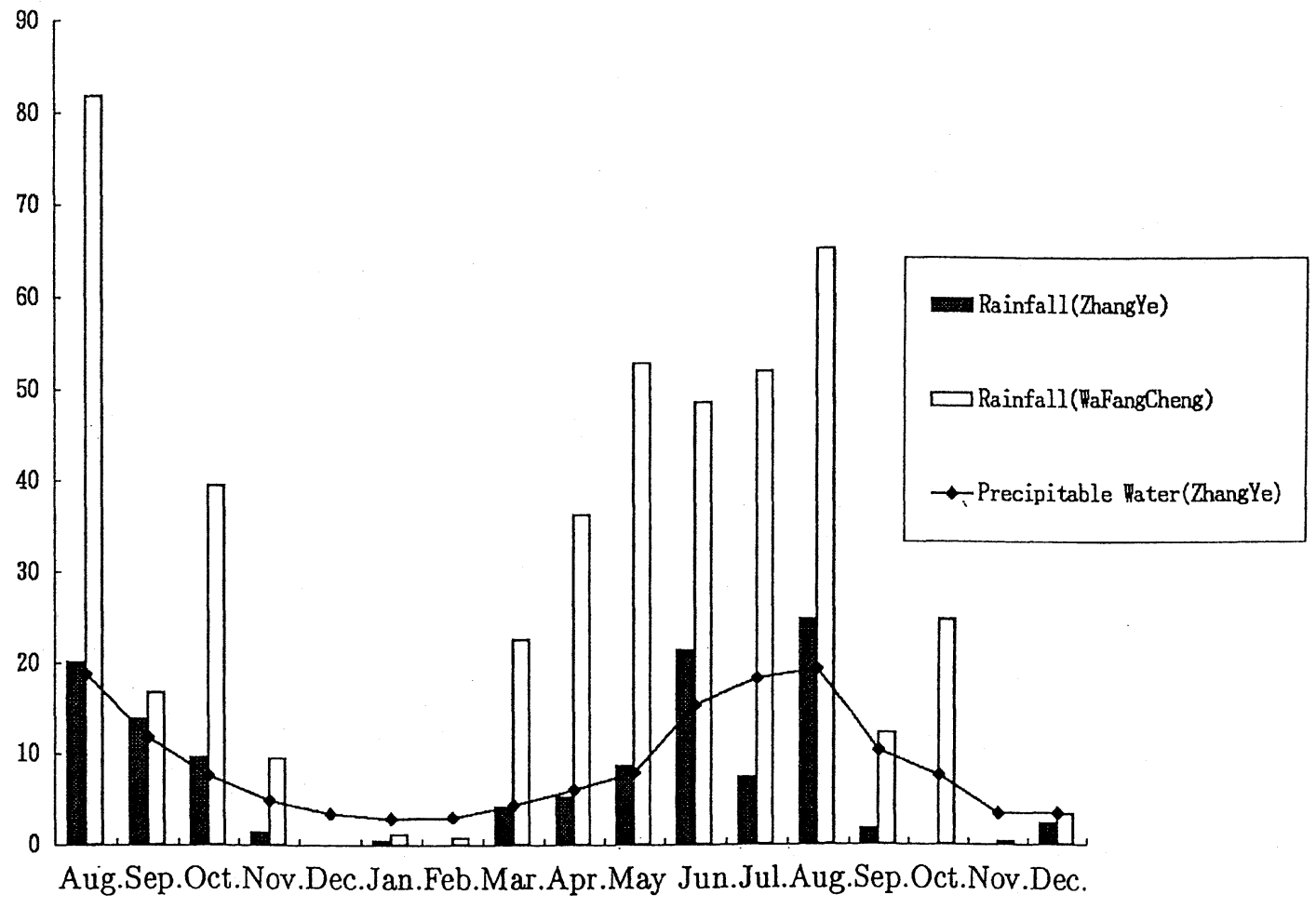

Fig. 8. Monthly mean precipitable water at ZhangYe, and monthly rainfall at ZhangYe and WaFangCheng from August 1991 to December 1991. 


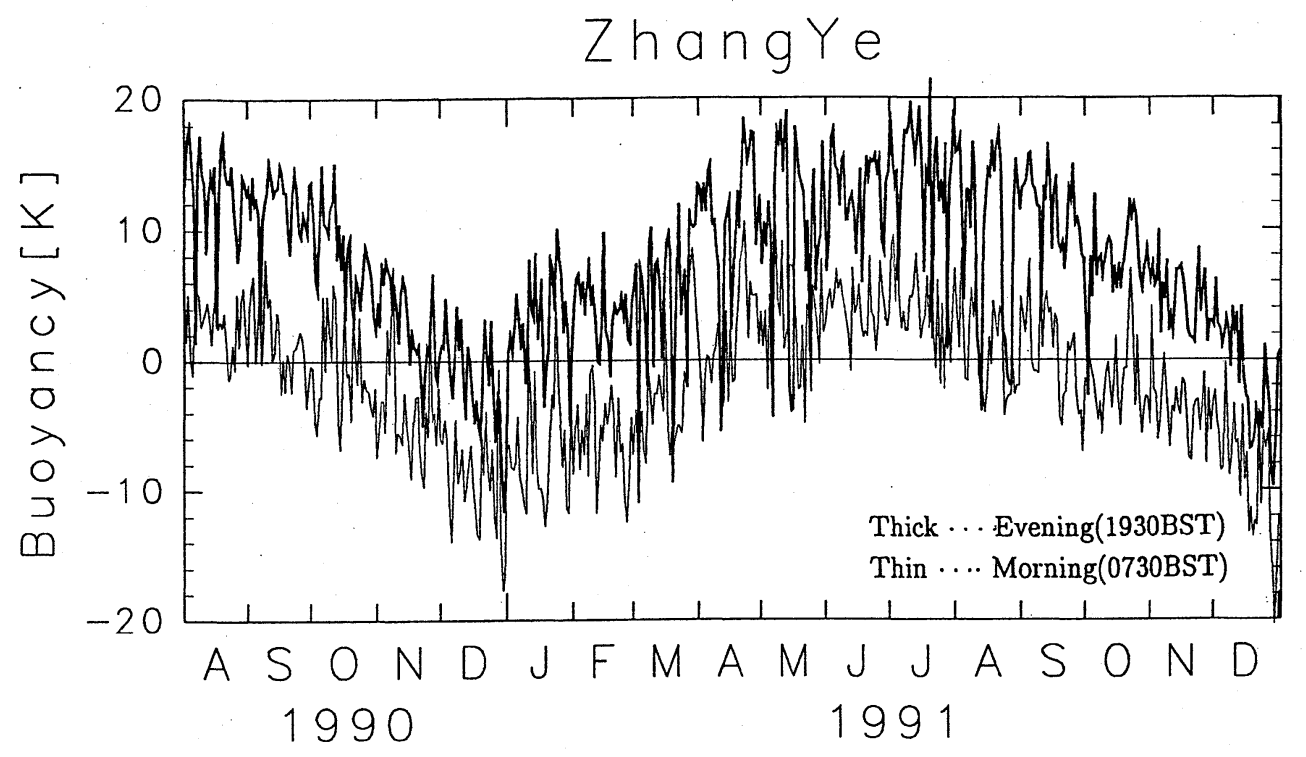

Fig. 9. Time series of the buoyancy at ZhangYe from August 1,1990 to the end of 1991 . The thin line shows that in the morning (0730 BST) and the thick line that in the evening (1930 BST). Positive and negative values mean that the condition is potentially unstable and absolutely stable, respectively.

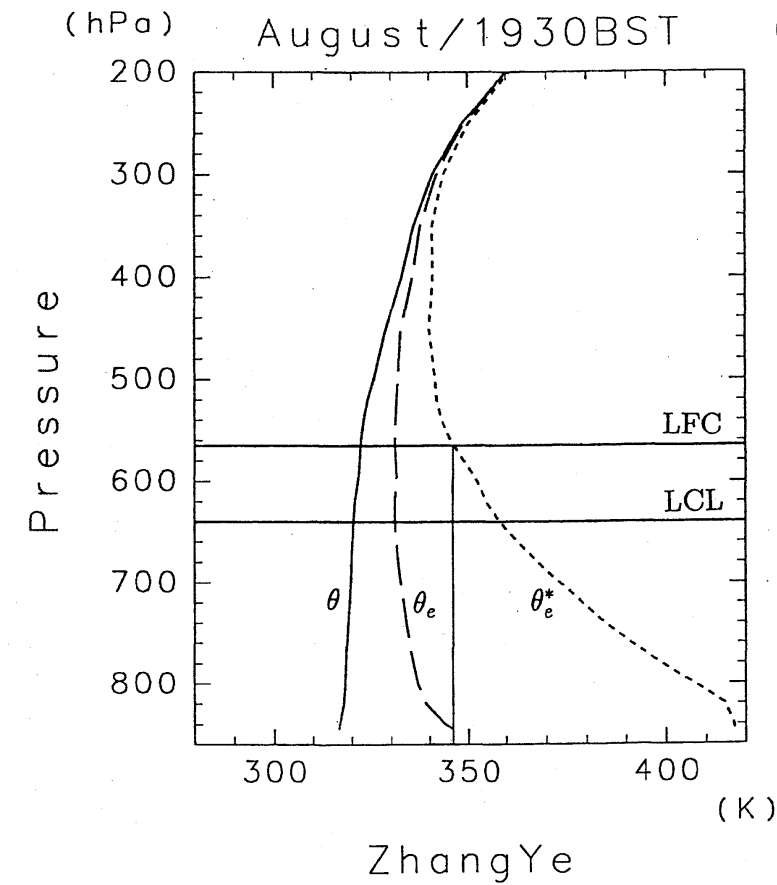

(a)

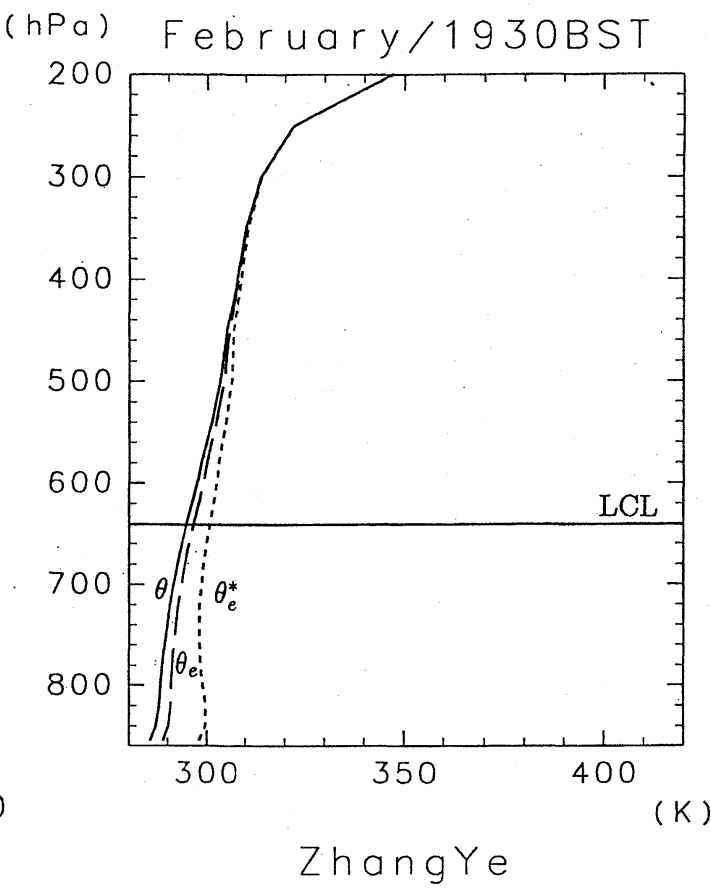

(b)

Fig. 10. Vertical profiles of monthly mean potential temperature (solid line), equivalent potential temperature (broken line) and saturated equivalent potential temperature (dotted line) at ZhangYe for clear days of (a) August 1991 and (b) February 1991 at 1930 BST. The lifting condensation level (LCL) and level of free convection (LFC) are also drawn with solid horizontal lines.

at WaFangCheng in the Qilian Mountains which is close by ZhangYe but much higher in elevation. The monthly rainfall at WaFangCheng was about 2.6 times that of the precipitable water at ZhangYe.

\subsection{Stability and stratification}

The stability of the air is also an important factor in the occurrence of rainfall. Xu and Emanuel (1989) defined "Buoyancy" as the virtual temperature difference between the adiabatically lifted surface air and the ambient air at the same altitude. 
In this study, the virtual temperature difference between a parcel of surface air (at around $850 \mathrm{hPa}$ ) lifted up to $500 \mathrm{hPa}\left(T_{v 500 \text { (lifted) }}\right)$ and the ambient $500 \mathrm{hPa}$ air $\left(T_{v 500 \text { (ambient })}\right)$ is compared as,

$$
\text { "Buoyancy" }=T_{v 500(\text { lifted })}-T_{v 500(\text { ambient })} \text {. }
$$

If the water vapor condenses during lifting, the condensed water is assumed to accompany the air parcel. So, the "Buoyancy" used in this study tends to be smaller than that in usual pseudoadiabatic analyses (where the condensed water is assumed to fall out of the lifted air parcel soon after their formation). And, apparently, positive "Buoyancy" means that the atmosphere is unstable for the air parcels rising from the surface.

The time series of the "Buoyancy" in the morning (0730 BST) and evening (1930 BST) at ZhangYe are shown in Fig. 9. Diurnal variations are quite large, and reach around $10 \mathrm{~K}$, presumably due to intense radiative heating at the surface in the daytime and cooling in the nighttime. During the summer, the temperature of the lifted air parcel is higher than the ambient air by almost $15 \mathrm{~K}$ in the evening and the "Buoyancy" shows slight instability even in the morning. So, if the surface air is lifted to the $500 \mathrm{hPa}$ level, convection is expected to occur in the HEIFE area in summer. However, although the profile shows unstable stratification for moist convection, the lifting condensation level (LCL) is as high as $640 \mathrm{hPa}(2350 \mathrm{~m}$ above the ground) on fine days in summer (Fig. 10a). Furthermore, the level of free convection (LFC) is still higher, i.e. $570 \mathrm{hPa}$. Under such circumstances, it seems difficult for the air parcel within the desert boundary layer to be carried up to the condensation level and form cumulus clouds in spite of the daytime heating at the surface. In fact, observation made by a sodar showed that the maximum mixed layer height at Huayin in the desert of HEIFE area was about $850 \mathrm{~m}$ above the ground (about $780 \mathrm{hPa}$ ) on a fine day in August, 1990 (Pan et al., 1992), which seems much lower than the LCL and LFC over this area shown in Fig. 10a. A trigger which lifts the surface air parcel at least to around the $570 \mathrm{hPa}$ level is necessary for the formation of the cloud and the occurrence of rainfall. Because of unstable stratification of the atmosphere, convection could be severe once it occurs. In fact, a storm which brought $30 \mathrm{~mm}$ of rainfall within six hours, which corresponds to one third of the annual rainfall, was reported near LinZe in this HEIFE desert area (Mitsuta et al., 1995).

In winter, "Buoyancy" is often positive in the evening, but not as large in magnitude as in summer and the air becomes absolutely stable in the morning. For several days around December, the atmospheric condition becomes completely stable from morning through evening. The LCL still remains high, and the air is so stably stratified that we can

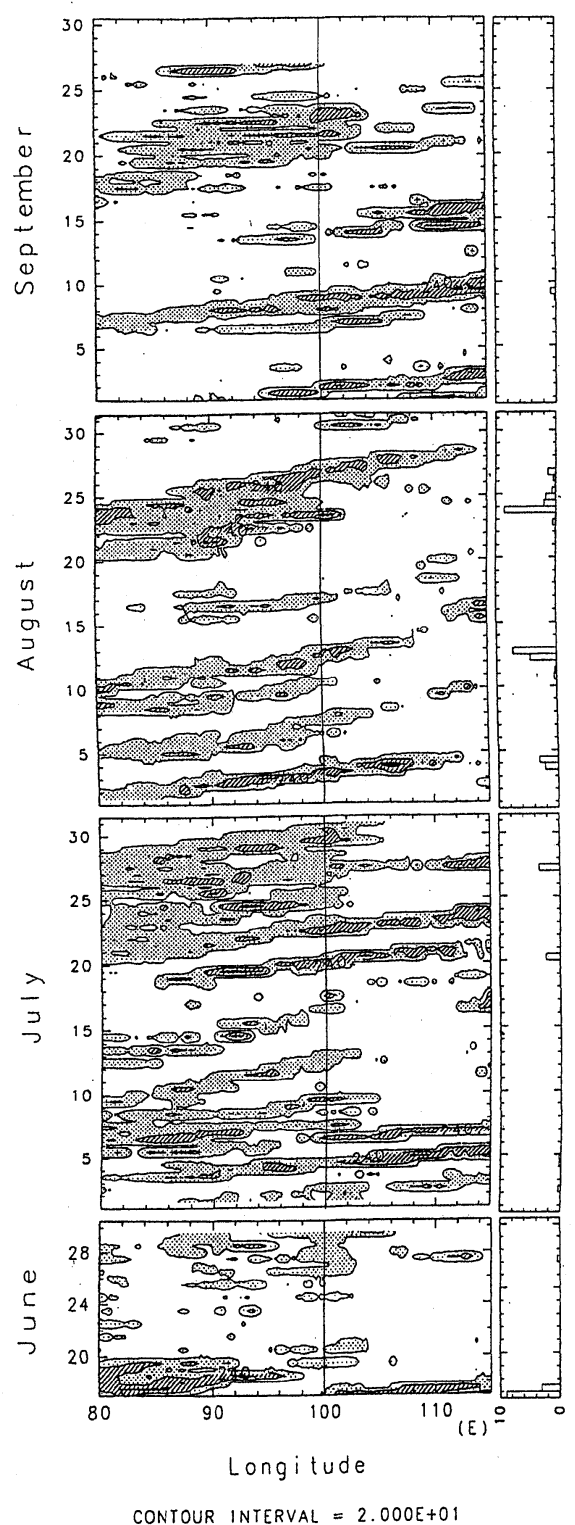

Fig. 11. Time-longitude section of Black Body Temperature $\left(T_{B B}\right)$ along $40^{\circ} \mathrm{N} \pm 2.5^{\circ}$ for Jun. 17-Sep. 30, 1991. $T_{B B}$ is classified into three categories and drawn with light $(240-260 \mathrm{~K})$, mod$\operatorname{erate}(220-240 \mathrm{~K})$ and heavy $(-220 \mathrm{~K})$ shade respectively. Time series of the twice-a-day rainfall record averaged over GaoTai, LinZe and ZhangYe is also drawn on the right.

not define the LFC as shown in Fig. 10b. Thus, rainfall is not expected to occur in winter.

\section{Occurrence of rainfall over the desert}

The occurrence of rainfall over the desert is analyzed using the GMS infrared data. The timelongitude section of cloud top Black Body Temperature $\left(T_{B B}\right)$ along $40^{\circ} \mathrm{N} \pm 2.5^{\circ}$ latitude for warm seasons (Jun. 17-Sep. 30, 1991) is shown in Fig. 11 together with the twice-a-day rainfall average 


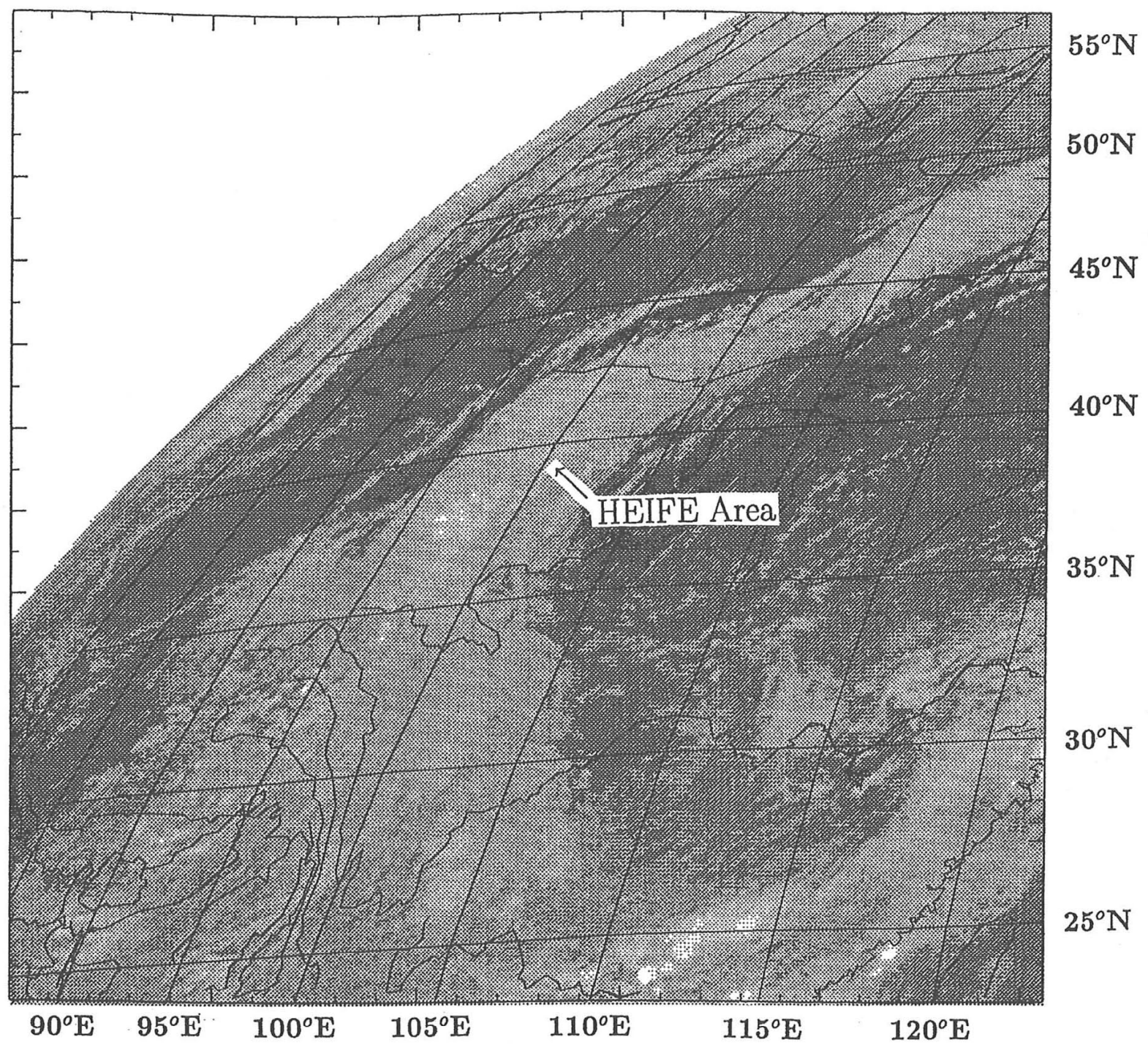

Fig. 12. The GMS S-VISSR infrared image at 1225 BST on August 12, 1991.

of ZhangYe, LinZe and GaoTai. In this diagram, the successive eastward-moving high clouds corresponding to the movement of a polar front are seen throughout the observation period, and only when these disturbances reached $100^{\circ} \mathrm{E}$, were rain events recognized in the HEIFE area. In other words, all rainfalls in the HEIFE area during this period were related to such disturbances. From the figure, the global east-west wave number of these disturbances is estimated to be $6-7$ and the period to be $5-6$ days, and they move eastward by about $10^{\circ}$ per day.

The GMS infrared image at 1225 BST of August 12, 1991, shown in Fig. 12, is a typical example of the disturbances mentioned above. In the figure, the zonal cloud band of the polar front extending from Siberia to the northern part of the Tibetan Plateau is just intersecting the HEIFE area around $100^{\circ} \mathrm{E}$, and rainfall is observed there for about 4 days around this time. Fig. 13 shows the objectively analyzed $500 \mathrm{hPa}$ contour map at $08 \mathrm{BST}$ of August
12. The vertical cross sections of the wind component normal to the cross section and the equivalent potential temperature along the line from Duhuang to Xian (see Fig. 1) are shown in Fig. 14, which also shows the regions with high relative humidities larger than $80 \%$ by shading. The northeastward jet and the humid cloud region at the warm sector side of the jet in Fig. 14 corresponds to the jet stream seen in Fig. 13 and the zonal cloud band in Fig. 12, respectively.

Figure 15 shows the daily rainfall distributions in the HEIFE area during August 10-13 with the contour of $2000 \mathrm{~m}$ and the Heihe river (see Fig. 2). These rainfall amounts are daily values just between $08 \mathrm{BST}$ of the date shown in the figure and the next day. The series of rainfall was brought by the polar frontal clouds seen in Fig. 12. In Fig. 14, this cloud area is first recognized on Aug. 11 (08 BST) as the region with high relative humidity appearing around $97^{\circ} \mathrm{E}$ between 500 and $750 \mathrm{hPa}$. The humid cloud 


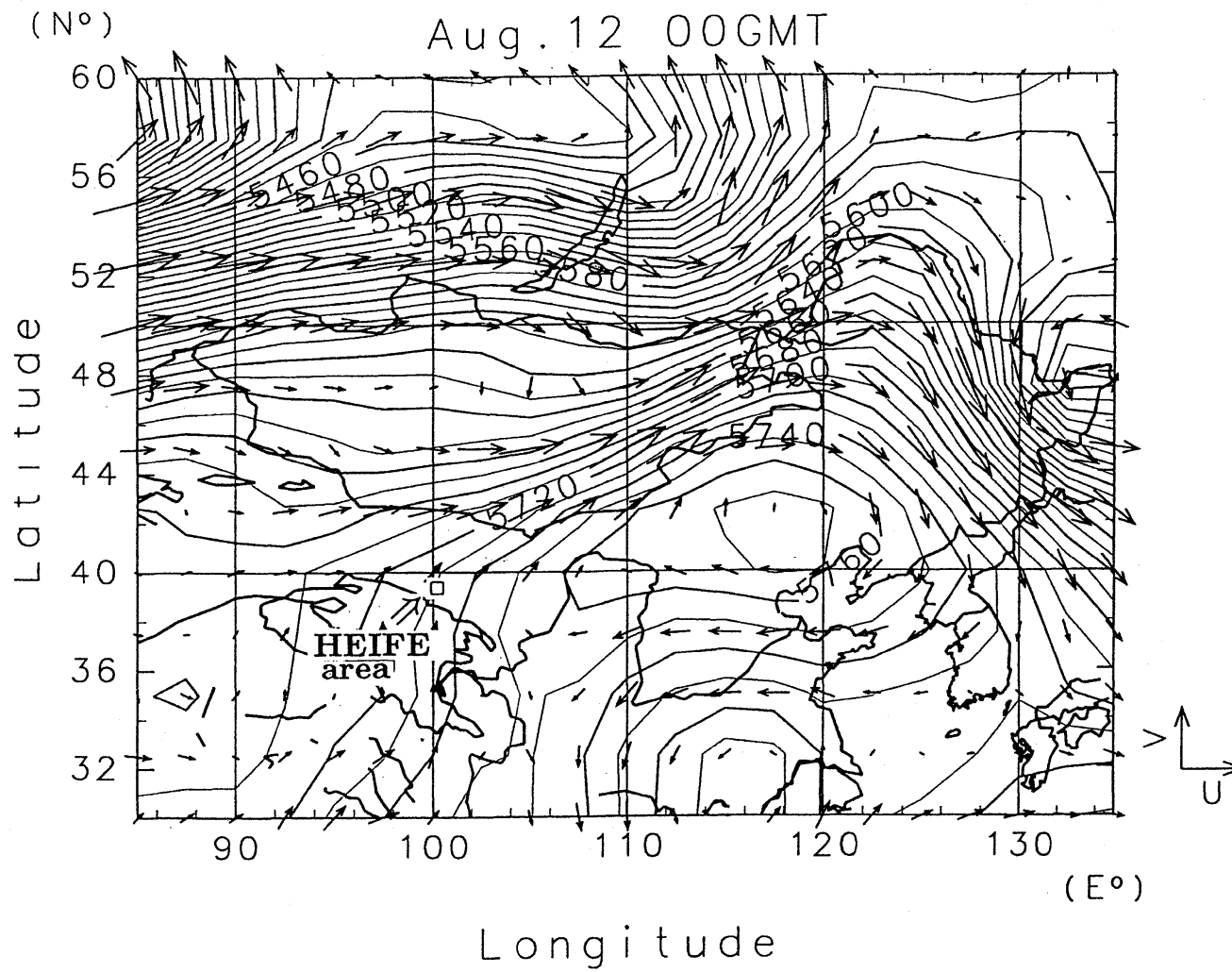

CONTOUR INTERVAL $=1.000 E+01$

\author{
XUNIT $=2.000 E+01, \quad$ YUNIT $=2.000 E+01$
}

Fig. 13. $500 \mathrm{hPa}$ contours (solid lines) and wind field (arrows) on August 12 (08 BST), 1991 by ECMWF objectively analysis data(contour interval is $10 \mathrm{~m}$ and unit vectors shown on the lower right of the figure indicate $20 \mathrm{~m} \mathrm{~s}^{-1}$ ).

region developed upward on successive days, and at the same time, has caused the rainfall in the HEIFE area.

During the 24 hours of Aug. 10, a light rainfall of about $1 \mathrm{~mm} \mathrm{day}^{-1}$ was observed in the western mountainous part of the area. Meanwhile, many stations in the Qilian Mountain sides observed the rainfall on Aug. 11, and the amount increased with the elevation of the station. At this time, the high relative humidity region in Fig. 14 had not yet reached the ground level of ZhangYe (around $850 \mathrm{hPa}$ ), but already reached halfway up the Qilian Mountain slopes $(700 \mathrm{hPa})$. Because the air in the desert boundary layer is dry, as shown in Fig. 7, the raindrops formed in the upper atmosphere may evaporate before reaching the ground surface. Then in the early stage of a rain event, the air below the cloud base is moistened but no rainfall is observed at the bottom surface. Over this arid area, it seems to take about two days for the high relative humidity region to reach the surface at the $850 \mathrm{hPa}$ level. However, once the whole airspace under the cloud base is moistened, significant rainfall occurs, even in the desert, at lower elevations. In this case, the high relative humidity region reached the ground level at ZhangYe by Aug.13 (08 BST) and heavy rainfall greater than $10 \mathrm{~mm} /$ day occurred on Aug. 12 at most of the stations in the HEIFE area. The upper front was seen in Fig. 14 just over the HEIFE area $\left(100^{\circ} \mathrm{E}\right)$ between 300 and $600 \mathrm{hPa}$ on Aug. 13 (08 BST). Because this front had passed to the east by Aug. 14 (08 BST), weak rainfall occurred only around the eastern border of the HEIFE area on Aug. 13.

The difference in the rainfall amount between the lower and higher elevated stations shown in Fig. 3 may be the result of such a process due to the evaporation of raindrops in the early stage of rain events. The orographic rainfall phenomenon can not fully explain such a difference because during the passage of the front, the wind is usually blowing northeastward from the Qilian Mountain down to the desert (see Fig. 14) and the higher elevated stations are located on the leeward sides of the mountains.

Time series of the various meteorological elements at ZhangYe in August, 1991 are shown in Fig. 16. 

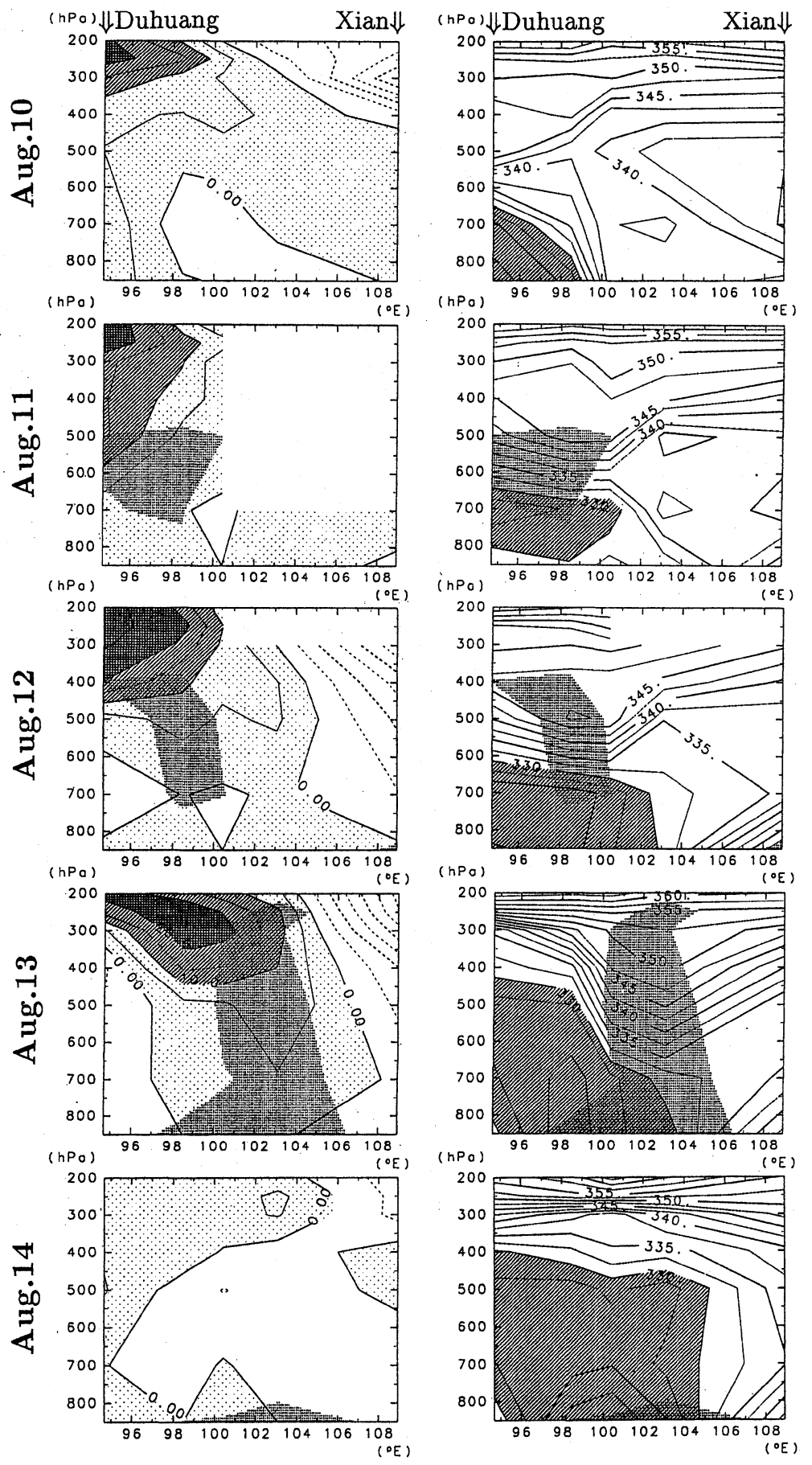

Wind(normal comp.)

Equiv.Potent.Temp.

Fig. 14. Vertical cross sections between Duhuang and Xian at 08 BST. Left figures show isolines of the wind component normal to the cross section(contour interval is $5 \mathrm{~m} \mathrm{~s}^{-1}$ with positive NE-ward and the regions between $0.0-10.0 \mathrm{~m} \mathrm{~s}^{-1}$ are stippled, $10.0-20.0 \mathrm{~m} \mathrm{~s}^{-1}$ hatched and over $20.0 \mathrm{~m} \mathrm{~s}^{-1}$ cross hatched heavily, respectively). Right-hand figures show isotherms of the equivalent potential temperature(contour interval is $5 \mathrm{~K}$ and the regions with equivalent potential temperature below $330 \mathrm{~K}$ are hatched). Regions with relative humidities larger than $80 \%$ are also shaded. 

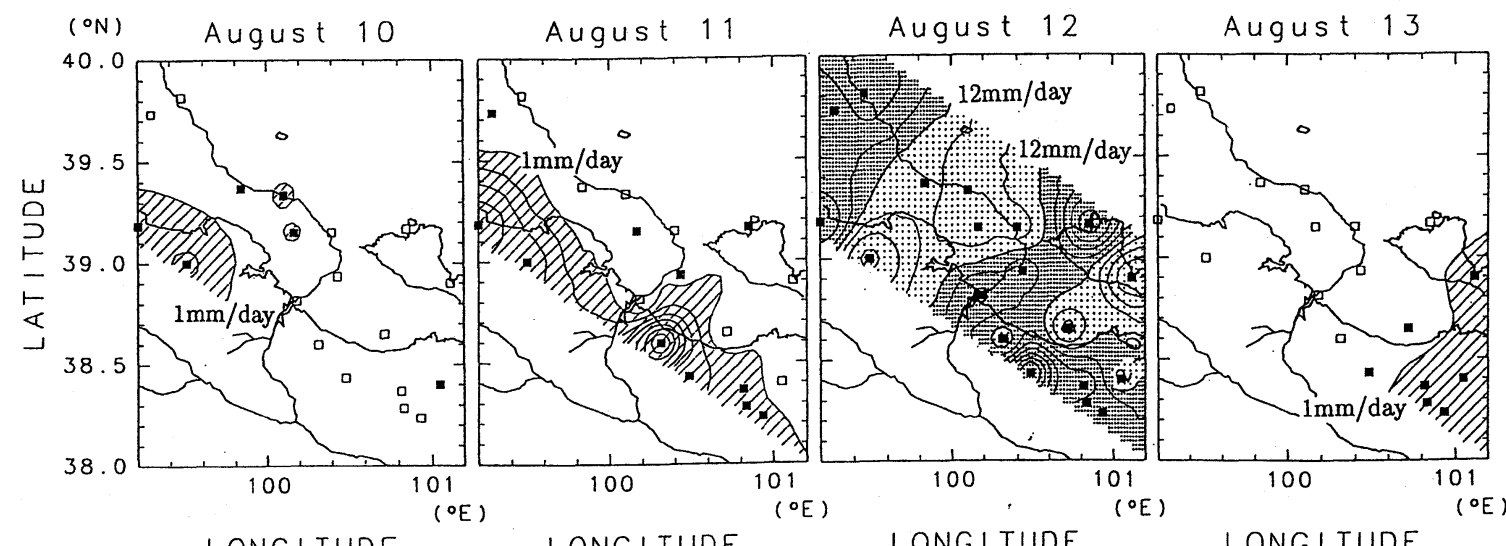

LONG I TUDE

LONGITUDE

LONGI TUDE

LONGI TUDE

Fig. 15. Distributions of daily rainfall within the HEIFE area(contour interval is $1 \mathrm{~mm} /$ day). Locations of stations where rainfall was observed are shown by closed squares and no rain by open squares. Areas with rainfall between 1-8 mm/day are hatched, $8-12 \mathrm{~mm} /$ day and over $12 \mathrm{~mm} /$ day shaded lightly and heavily, respectively.

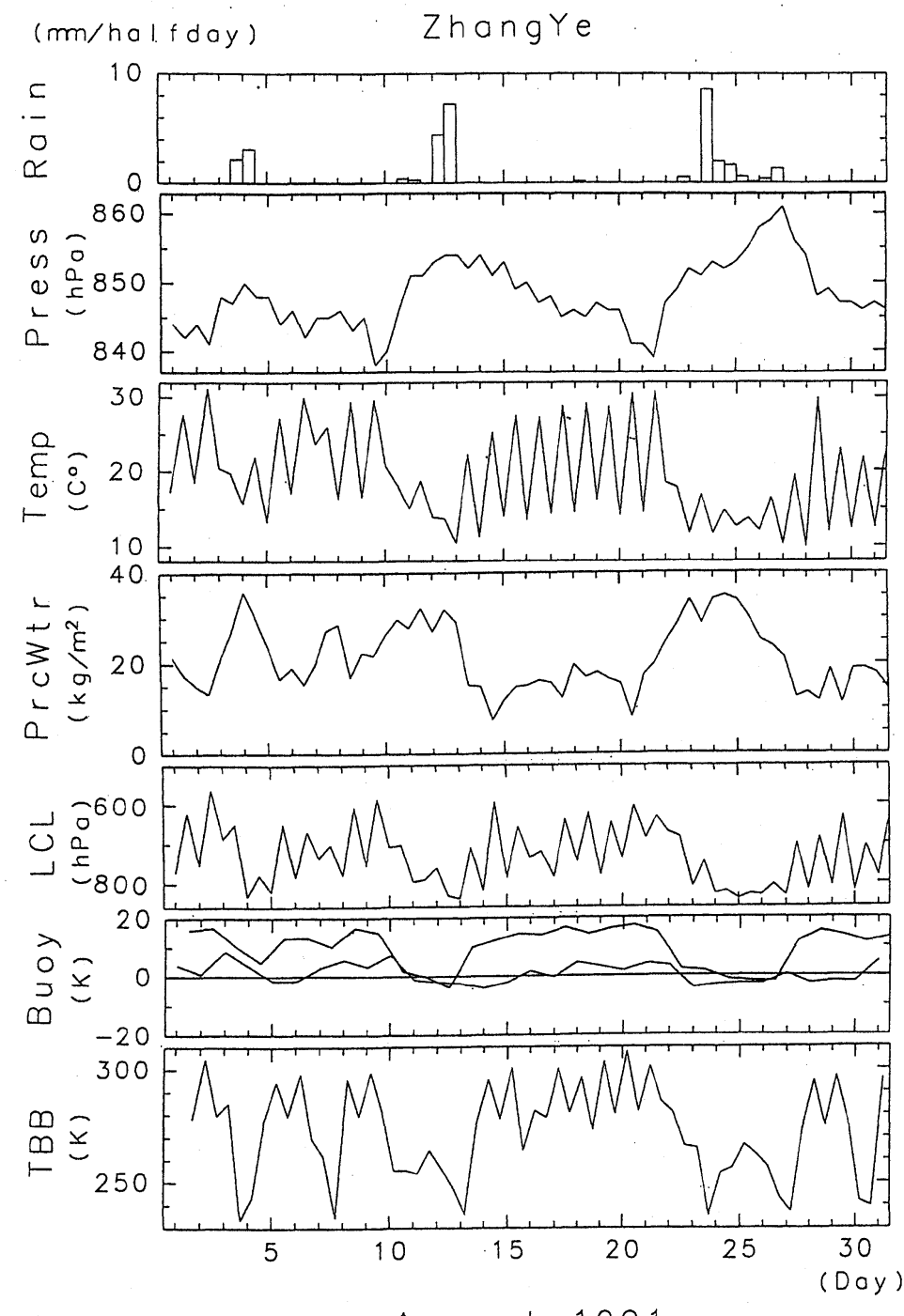

August 1991

Fig. 16. Time series of various weather elements at ZhangYe during August in 1991. From the top, twice-a-day rainfall amount $\left(\mathrm{mm} /\right.$ half a day), surface pressure $(\mathrm{hPa})$, surface air temperature $\left({ }^{\circ} \mathrm{C}\right)$, precipitable water $\left(\mathrm{kg} / \mathrm{m}^{2}\right)$, lifting condensation level $(\mathrm{hPa})$, buoyancy $(\mathrm{K})$ and $T_{B B}(\mathrm{~K})$ obtained from satellite data, respectively. Time series of the buoyancy at 0730 BST (thin line) and 1930 BST (thick line) are drawn separately in the same way as in Fig. 9. 
During that month, three major rain events were observed and all of them were related to disturbances moving from the west as shown above. In the case of the rainfall during Aug. 10-13, the precipitable water began to increase on Aug. 8. The time of passage of the surface front at ZhangYe was estimated to be around Aug. 10(08 BST) because the air temperature showed a sharp decrease and the surface pressure an increase at that time. However, the air temperature continued to decrease and the surface pressure to increase until Aug. 13 (08 BST), when the main rainfall started. During this period, the diabatic cooling due to the evaporation of raindrops within the desert boundary layer might have occurred. Therefore, the main rainfall in the bottom part of the Hexi Corridor was delayed by three days from the passage of the surface front and the surface pressure showed high values during the whole rain event as Sahashi (1995) pointed out.

Once rainfall starts, the buoyancy becomes zero, so that the instability disappeared, and the LCL decreased because surface relative humidity becomes large. After the rainfall, the precipitable water drops, and the surface pressure and the air temperature recover gradually showing a typical diurnal variation on fine days. Meanwhile, a high LCL and the potential instability was re-established.

Similar patterns of rainfall occurred repeatedly in the course of the study. It can be said that this example shows the typical nature of rainfall in the arid area in northwestern China.

\section{Conclusions}

Rainfall characteristics and atmospheric conditions over the HEIFE area are examined. Generally, a significant amount of rainfall is observed in summer with less precipitation in winter. Each rainfall is caused by synoptic disturbances on the polar front and occurs simultaneously in an area of $200 \times 100 \mathrm{~km}$. However, the amount of rainfall depends strongly on the elevation. Because the raindrops formed in the upper and middle atmosphere may evaporate within the dry desert boundary layer before reaching the ground surface, the rainfall over the lower land of the HEIFE area is significantly reduced. In fact, annual rainfall at the bottom part of the Hexi Corridor is only $100 \mathrm{~mm} /$ year or less, while it becomes about $600 \mathrm{~mm} /$ year at $3000 \mathrm{mASL}$ in the Qilian Mountains.

The analysis of aerological data shows that the precipitable water over the HEIFE area is rather large in summer. The atmosphere over the HEIFE area has a water vapor content of more than $75 \%$ that at the same altitudes over tropical humid areas in summer. Moreover, the air above the desert shows a large potential instability. However, the LCL and LFC over the desert are quite high due to low relative humidity in the planetary bound- ary layer, which seems to prevent the development of small-scale cumulus cloud convections from the thermals generated near the surface. As a result, the rainfall over the HEIFE area occurs only when well defined synoptic disturbances on the polar front move into this area.

In winter, on the contrary, the water content is quite small and the LCL remains high. In addition, buoyancy is smaller than in summer, which results in low precipitation during winter.

\section{Acknowledgment}

This work has been done as a part of the SinoJapanese cooperative HEIFE program. The author would like to express deepest thanks to Prof. Y. Mitsuta for his continuous guidance and encouragement throughout this work. Thanks are also due to Dr. T. Kobayashi, Ms. Y. Mizobe and Mr. D.M. Cox for revising the manuscript and their encouragement.

\section{References}

Broccoli, A.J. and S. Manabe, 1992: The effects of orography on midlatitude Northern Hemisphere dry climates. J. Climate, 5, 1181-1201.

Domrös, M. and G. Peng 1988: The Climate of China. Springer-Verlag, 360pp.

Jordan, E.S., 1958: Mean soundings for the West Indies area. J. Meteor., 9, 340-346.

Kitoh, A., K. Yamazaki and T. Tokioka, 1993: Summertime moisture flux in the desert regions of western China. J. Arid Land Studies, 3, 9-17 (in Japanese with English summary).

Lau, K.-M., G.J. Yang and S.H. Shen, 1988: Seasonal and interseasonal climatology of summer Monsoon rainfall over East Asia. Mon. Wea. Rev., 116, 1837.

Manabe, S., 1969: Climate and the ocean circulation: I. The atmospheric circulation and the hydrology of the earth's surface. Mon. Wea. Rev., 97, 739-774.

Manabe, S. and A.J. Broccoli, 1990: Mountains and arid climates of middle latitudes. Science, 247, 192-195.

Mitsuta, Y., T. Hayashi, T. Takemi, Y. Hu, J. Wang and M. Chen, 1995a: Severe local storms as observed in the arid area of northwest China. J. Meteor. Soc. Japan, 73, 1269-1284.

Mitsuta, Y. and T. Itano, 1993: Precipitable water and water vapor flux over HEIFE area. Proc. Int. Symp. HEIFE., 242-251.

Pan, T., Y. Hu, P. Lin and Y. Mitsuta, 1992: An analysis on the vertical structure of wind field sounded by doppler sodar at Huayin. Bull. Disast. Prev. Res. Inst., Kyoto Univ., 42, 115-124.

Rossby, C.-G., 1957: Current problems in meteorology. Svensk Naturvetenskap 1956, 15-80. English translation, 1959: The Atmosphere and Sea in Motion, B. Bolin, Ed. New York, Rockefeller Inst. Press, 9-50.

Sahashi, K., 1995: A wet period in the desert station in HEIFE. J. Meteor. Soc. Japan, 73, 1213-1217.

Walker, J. and P.R. Rowntree, 1977: The effect of soil moisture on circulation and rainfall in a tropical model. Quart. J. Roy. Meteor. Soc., 103, 29-46. 
Wang, J., 1993: Geography and landuse of Hexi Corridor. Proc. Int. Symp. HEIFE., 16-21.

Wang, W.-C. and K. Li, 1990: Precipitation fluctuation over semi arid region in Northern China and the relationship with El Niño/Southern Oscillation. J. Climate, 3, 769-783.

Xu, K.-M. and K.A. Emanuel, 1989: Is the tropical atmosphere conditionally unstable? Mon. Wea. Rev., 117, 1471-1479.

Yanai, M., C. Li and Z. Song, 1992: Seasonal heating of the Tibetan Plateau and its effects on the evolu- tion of the Asian summer monsoon. J. Meteor. Soc. Japan, 70, 189-221.

Yatagai, A. and T. Yasunari, 1995: Interannual variations of summer precipitation in the arid/semi-arid regions in China and Mongolia: Their regionality and relation to the Asian summer monsoon. J. Meteor. Soc. Japan, 73, 909-923.

Ye, D., 1981: Some characteristics of the summer circulation over the Qinghai-Xizang(Tibet) plateau and its neighborhood. Bull. Amer. Meteor. Soc., 62, 1419.

\title{
中国北西部・乾燥地域における降雨 \\ 一HEIFE期間における解析一
}

\author{
板野榆久 \\ （京都大学防災研究所）
}

中国北西部の乾燥地域に位置する HEIFE 領域の降水の特性について調べた。

HEIFE 領域の降雨は総観規模の擾乱によって引き起こされ、このため約 $200 \times 100 \mathrm{~km}$ の HEIFE 領域に おいて降水はほほ同時に観測される。しかし、観測される降雨量は標高に大きく依存し、Qilian 山脈中腹 の標高 $3000 \mathrm{~m}$ の地点では $600 \mathrm{~mm} / \mathrm{year}$ 以上の降雨が観測される一方、標高の低い河西回廊と呼ばれる谷 間の底部では $100 \mathrm{~mm} / \mathrm{year}$ 以下の降雨しか観測されない。

大気中の水蒸気密度の鉛直プロファイルを調べてみると、夏の間には乾燥地域とはいえ少なからぬ量の 水蒸気が観測され、また、安定度の点でも大きな条件付き不安定を示すことがわかった。しかし、持ち上 げ凝結高度(LCL)および自由対流高度(LFC)がともに高いので、高い地表面温度によって大気が不安定化 されるにもかかわらず局地的な積雲対流は見られず、結局極前線上の波動擾乱がやってきたときにだけ降 水が見られる。しかし、この時多くの雨粒は地表に届く前に深くて乾燥した砂漠上の境界層内で蒸発して しまうものと思われる。このため、領域内の標高の低い地域で観測される降水量は著しく減少する。一方、 冬の間は水蒸気量・安定度の両方の点において降水があまり期待できない。

\footnotetext{
${ }^{1}$ 現在所属: 防衛大学校地球科学科
} 